\section{Provenancing variscite beads: Pico Centeno (Encinasola, Spain) outcrop case study}

\author{
Carlos P. Odriozola, ${ }^{1}$ \\ José A. Linares-Catela, ${ }^{2}$ \\ Victor M. Hurtado-Pérez ${ }^{3}$ \\ 'Departamento de Prehistoria y \\ Arqueología, Universidad de Sevilla; \\ ${ }^{2}$ Cota Cero GPH S.L., Huelva; \\ ${ }^{3}$ Departamento de Prehistoria y \\ Arqueología, Universidad de Sevilla, \\ Sevilla, Spain
}

\begin{abstract}
In this study we discuss the exploitation and exchange of variscite at Pico Centeno mining district during the Copper Age. X-ray fluorescence and diffraction (XRF and XRD, respectively) and Fourier transform infrared spectroscopy (FTIR) analyses of the mineral recovered at Pico Centeno mining district provides a baseline mineral signature, which was then compared to other Iberian sources and beads from SW Iberian megalithic tombs. We found that the concentrations of trace elements don not allow establishing provenance of the beads, as traditionally claimed. Instead we found that different proportions of phosphate species, which results in P/Al ratios higher than 1, arose during the genesis of the variscite deposits, modifying the concentrations of $\mathrm{PO}_{4}{ }^{3-}, \mathrm{H}_{2} \mathrm{PO}_{4}{ }^{-}$and $\mathrm{HPO}_{4}{ }^{2-}$. Thus, the $\mathrm{P} / \mathrm{Al}$ atomic ratio should be an indication of provenance as it is established during mineral genesis.
\end{abstract}

\section{Introduction}

Variscite was heavily traded in prehistoric Europe, particularly in the Iberian Peninsula, and is a strong candidate for provenience studies. A high degree of precision and accuracy in locating sources can be achieved due to the limited number of known geological sources. Western European variscite sources are rare and actually there are known only 8 variscite sources (Figure 1): Pannecé (Loire-Atlantique, France), Montebras (Creuse, France), Sarrabús (Sardinia), Palazuelos (Aliste, Zamora, Spain), Tras-o-Montes (Bragança, Portugal), Punta Corbeiro (Sanxenxo, Pontevedra, Spain), Can Tintorer (Gavá, Barcelona, Spain) and Pico Centeno (Encinasola, Huelva, Spain).

In this study we discuss the exploitation of variscite at Pico Centeno during the Copper
Age. X-ray fluorescence and diffraction (XRF and XRD, respectively) analyses of the mineral at the mined outcrops provided a baseline mineral signature for the source, which was then compared to variscite beads from 8 megalithic tombs from two different regions. In the Middle Guadiana Basin we analyzed beads from Perdigões (Reguengos de Monsaraz, Portugal) tholoi 1 and 2 (Valera et al., 2002) and La Pijotilla (Badajoz, Spain) T3 tholos (Hurtado, 1986, 1991). From the Andévalo Oriental in Huelva, Spain we analyzed beads from Dolmen 4 from Los Gabrieles (Linares Catela, 2006, 2009), Dólmenes de Puerto de los Huertos, Casullo and Mascotejo from El Gallego-Hornueco (Linares Catela, 2009) and, finally, Dolmen 2 from Pozuelo (Cerdán et al., 1975). Non-destructive compositional data were obtained using a $\mu$-XRF, while nondestructive XRD patterns were recorded with a parallel beam.

The variscite mineral group are orthorhombic phosphates with a general formula $\left[\mathrm{MPO}_{4} \cdot 2 \mathrm{H}_{2} \mathrm{O}\right]$, where $\mathrm{M}=\mathrm{Al}^{3+}, \mathrm{Fe}^{3+}, \mathrm{Cr}^{3+}, \mathrm{V}^{3+}$. Variscite is a secondary mineral formed by direct deposition of phosphatic groundwater descending along open fissures and reacting with aluminium-rich rocks (Larsen, 1942). It occurs as fine-grained masses in nodules, cavity fillings and crusts associated with clay rocks, typically of schist.

The relationship between beads and source is established by comparison of the chemical components of the beads and those of the sources. The validity of this approach rests in the fact that $[. .$.$] differences in chemical com-$ position between different natural sources exceed, in some way, the differences observed within a given source (Weigand et al., 1977).

\section{Materials and Methods}

The Pico Centeno Silurian Al (Fe-Ca) phosphate deposits are located at the vicinity of Encinasola (Huelva, Spain). As previously described by [9], these SW Iberian deposits are associated with the silurian lidite which are found in the NW of the region in the vicinity of Encinasola. Encinasola is part of the Hercynian mega-structure known as the Terena Synform.

We have sampled two previously reported variscite types - concretionary and massive variscite (Moro et al., 1992, 1995) after the archaeological survey of the Terena Synform and the excavation of Pico Centeno (PCM 2). The sampling focused on mining and production debris (flakes and rough out nodules), although samples from the extraction scars were also taken, as well as samples other outcrops (Sierra Cocha \& El Tejar) located in the Terena Synform in order to test source-to-
Correspondence: Carlos P. Odriozola, Departamento de Prehistoria y Arqueología, Universidad de Sevilla, C. María de Padilla S/N, 41004, Sevilla, Spain.

Tel/Fax: +34.954.551.415.

E-mail: carlos.odriozola@gmail.com

Key words: variscite, provenance, Cooper Age, Iberia, $\mu$-XRF.

Acknowledgements: the authors acknowledge the Junta de Andalucía, Consejería de Innovación, Ciencia y Tecnología for the financial support (P06-HUM-02159).

Citation: Odriozola CP, Linares-Catela JA, Hurtado-Pérez VM, 2013. Provenancing variscite beads: Pico Centeno (Encinasola, Spain) outcrop case study. In: RH Tykot (ed.) Proceedings of the $38^{\text {th }}$ International Symposium on Archaeometry May $10^{\text {th }}-14^{\text {th }} 2010$, Tampa, Florida. Open Journal of Archaeometry 1:e17.

Presented at the $38^{\text {th }}$ International Symposium on Archaeometry - May $10^{\text {th }}-14^{\text {th }} 2010$, Tampa, Florida.

This work is licensed under a Creative Commons Attribution 3.0 License (by-nc 3.0).

CC Copyright C.P. Odriozola et al., 2013 Licensee PAGEPress, Italy

Open Journal of Archaeometry 2013; 1:e17 doi:10.4081/arc.2013.e17

source chemical differences and variance.

Variscite geological samples and beads from Middle Guadiana basin and Andevalo Oriental megalithic contexts were analysed with an Eagle III EDAX $\mu$-XRF, by means of X-ray diffraction with a Siemens D5000 difractometer (Siemens, Munich, Germany), and with a Nicolet 510P Fourier transform infrared spectroscopy (FTIR).

A total of 38 geological samples were analysed. The reported data are the average five measurements. Furthermore, total of 44 beads were analysed from 8 Late Prehistoric burials of different architectural types and geographical regions in order to test distribution patterns and models.

Beads from Perdigões tholoi 1 and 2 were randomly sampled over 6000 . Due to the variety of bead shapes, the major sampling criteria was to insure all bead shapes were represented in the sample. In contrast, although 502 beads were recovered from La Pijotilla tholos T3, only three were sampled based on their greenish colour; the rest of the beads were white. The beads recovered from Gabrieles 4, Puerto de los Huertos, Casullo, Mascotejo and Pozuelo 2 megaliths from Andévalo Oriental were fully sampled. Although the Middle Guadiana megaliths are tholo $i$ and the Andévalo Oriental ones are of dolmens, both 
funerary architectural types can be chronologically ascribed to the $3^{\text {rd }}$ millennium $\mathrm{BC}$ (Figure 2).

\section{Results and Discussion}

The mineralogical characterisation revealed that the sampled green rocks from these sites are all variscite and the XRD patterns from Pico Centeno (Figure 3) indicate all are orthorhombic cryptocrystalline type $M$ variscite (International Centre for Difraction Data card 25-18).

The $\mu$-XRF analyses of different samples drawn from the same mine show considerable analytical variation for minor and trace elements. In some cases a coefficient of variation (CV) as high as $170 \%$ for a single element (Cr) (Moro et al., 1995). It is possible to observe in Figure 4 how the traditionally used as source-to-source discriminators (Odriozola et al., 2010; Querré et al., 2007) - mainly Cr

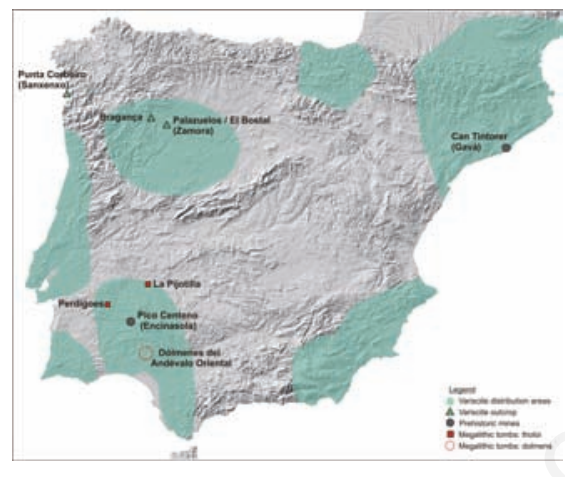

Figure 1. Location of the Western European, Iberian variscite sources and distribution areas. Location of the study cases: La Pijotilla and Perdigóes at the Middle Guadiana basin, and Andévalo Oriental megalithic region.

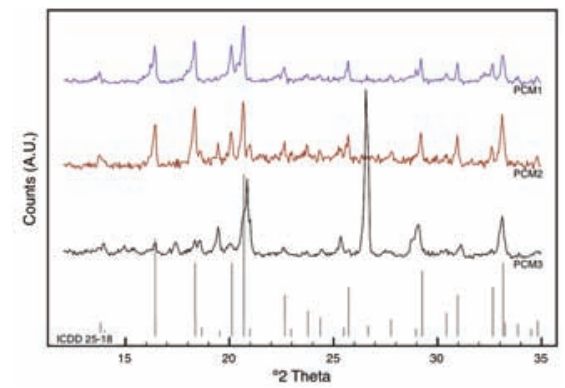

Figure 2. Radiocarbon probability plot of the studied megaliths (Odriozola et al., 2008; Linares Catela and García Sanjuán, 2010). and V - (Odriozola et al., 2010) cannot be used as source to source discriminator because their variability within a given source is bigger than a source to source variability for Iberian and French sources. Thus the repeated $\mu$-XRF analysis for the same sample does not closely agree in most elements and, in fact, can exhibit tremendous variability, with M1-1 and M3-1 samples that accounts for CV's as high as 87 $\left(\mathrm{Fe}_{2} \mathrm{O}_{3}\right), 62(\mathrm{~V})$ or $91 \%(\mathrm{Cr})$. These CVs prevents us of using these elements and their correlations as an indicator of provenance due to its high natural variability.

Thus, natural source mineral variability becomes an important barrier to variscite provenance analysis and therefore to its reliability in determining prehistoric exchange routes.

Variscite's ideal formula is $\left[\mathrm{AlPO}_{4} \cdot 2 \mathrm{H}_{2} \mathrm{O}\right.$ ] which means a P/Al atomic ratio equal to 1 , although aluminium substitutions for other trivalent transition ions $\left(\mathrm{Fe}^{3+}, \mathrm{Cr}^{3+}, \mathrm{V}^{3+}, \ldots\right)$ may slightly increase this ratio. This is consistent with most of the previously reported data

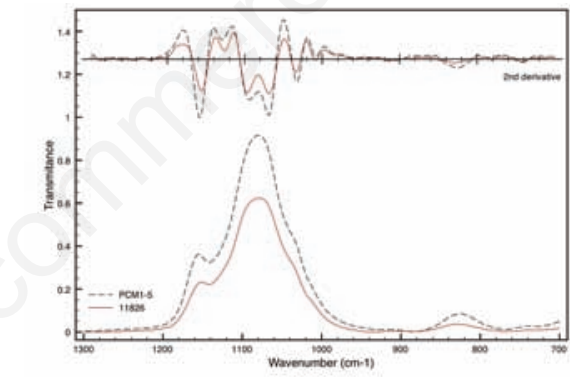

Figure 3. X-ray diffraction pattern of variscite samples from Pico Centeno mining complex (broken line) compared to ICDD card 25-18 peak position (red line).

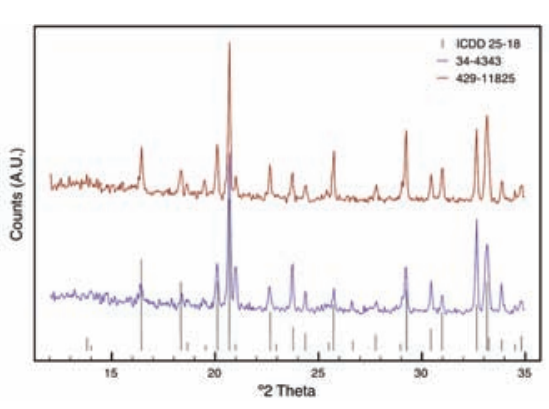

Figure 4. Box plot of P/Al (at\%), Cr and V.
(Odriozola et al., 2010), however, in our case this ratio is much higher than 1 , around 1.7. Despite this high ratio the XRD data unambiguously confirm that our material is type $\mathrm{M}$ variscite. For the El Tejar the measured P/Al ratio is closer to the one expected for pure stoichiometric variscite phase having a chemical composition equal to the ideal represented by $\mathrm{AlPO}_{4} \cdot 2 \mathrm{H}_{2} \mathrm{O}$ formula. This value is consistent with the ones previously reported (Moro et al., 1992). If we consider partial substitution of aluminium by other transition metals in the $\mathrm{P} / \mathrm{M}$ ratio, where $\mathrm{M}$ stands for the sum of the atomic percentages of aluminium and the rest of transition metals, the P/M ratio in our sample is still much higher than 1.

The existence of hydrogenphosphate anions in the variscite group minerals has been previously proposed. Frost et al. (2004) reported an
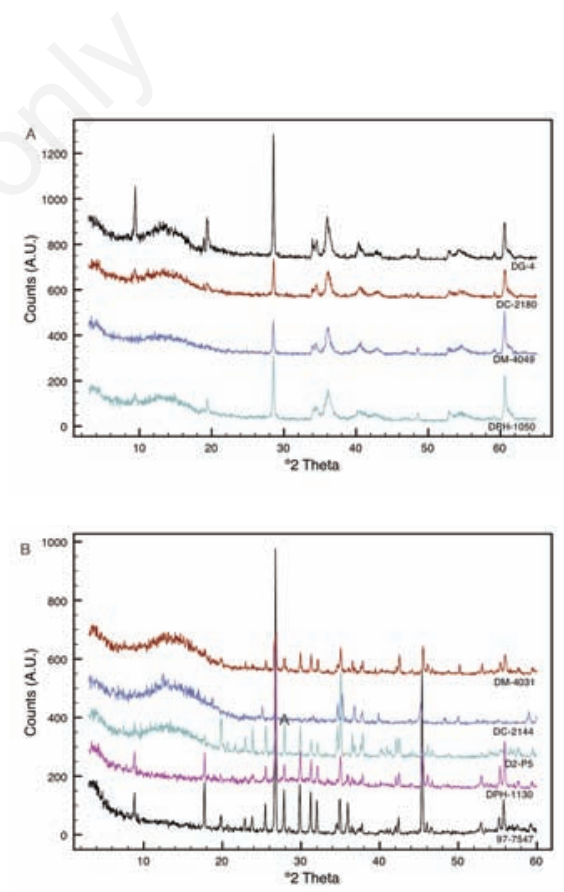

Figure 5. X-ray diffraction patterns of studied beads: A) variscite beads, B) talc beads.

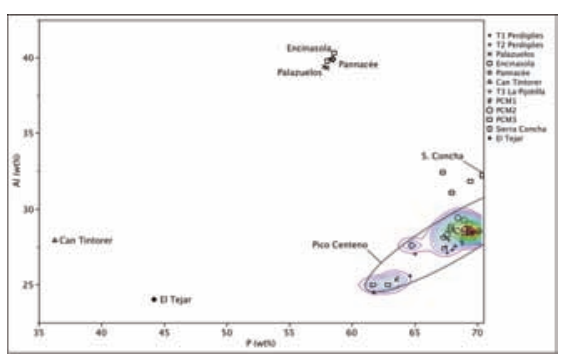

Figure 6. P vs Al (at \%) plot with $95 \%$ confidence ellipse fit of Pico Centeno samples compared to bibliographic data for western European variscite sources. 
Table 1. Mineral phase identification for the studied samples accomplished with bead type and measures.

\begin{tabular}{|c|c|c|c|c|c|c|c|}
\hline Code & $\begin{array}{l}\text { Megalithic } \\
\text { tomb }\end{array}$ & $\begin{array}{c}\text { XRD } \\
\text { (mineralogy) }\end{array}$ & Tipology & $\begin{array}{l}\text { Length } \\
\text { (mm) }\end{array}$ & $\begin{array}{l}\text { Width } \\
(\mathrm{mm})\end{array}$ & $\begin{array}{l}\text { Perforation } \\
\text { (mm) }\end{array}$ & Geographic area \\
\hline DP-2 & Pozuelo 2 & Muscovite & Biconical bead & 8.61 & 7.22 & 1.78 & Andévalo Oriental \\
\hline DG-4 & Gabrieles 4 & Talc & Cylindrical bead & 10.48 & 13.61 & 6.89 & Andévalo Oriental \\
\hline DC-2144 & Casullo & Muscovite & Biconical bead & 11.99 & 16.10 & 10.00 & Andévalo Oriental \\
\hline DC-2180 & Casullo & Talc & Cylindrical bead & 14.63 & 13.91 & 6.48 & Andévalo Oriental \\
\hline DM-4016 & Mascotejo & Talc & Barrel bead & 11.24 & 12.01 & 6.19 & Andévalo Oriental \\
\hline DM-4031 & Mascotejo & Muscovite & Biconical bead & 12.00 & 8.62 & 1.79 & Andévalo Oriental \\
\hline DM-4049 & Mascotejo & Talc & Barrel bead & 14.59 & 13.91 & 6.18 & Andévalo Oriental \\
\hline DPH-1050 & Puerto Huertos & Talc & Barrel bead & 13.68 & 11.49 & 4.99 & Andévalo Oriental \\
\hline DPH-1057 & Puerto Huertos & Muscovite & Spherical bead & 12.49 & 12.37 & 2.78 & Andévalo Oriental \\
\hline DPH-1067 & Puerto Huertos & Muscovite & Spherical bead & 8.03 & 10.52 & 2.52 & Andévalo Oriental \\
\hline DPH-1076 & Puerto Huertos & Talc & Cylindrical bead & 15.11 & 13.98 & 4.68 & Andévalo Oriental \\
\hline DPH-1082 & Puerto Huertos & Muscovite & Barrel bead & 7.69 & 6.27 & 2.39 & Andévalo Oriental \\
\hline DPH-1102 & Puerto Huertos & Talc & Spherical bead & 8.34 & 10.66 & 3.99 & Andévalo Oriental \\
\hline DPH-1108 & Puerto Huertos & Chlorite & Little discoidal bead & 0.91 & 5.26 & 2.03 & Andévalo Oriental \\
\hline DPH-1119 & Puerto Huertos & Talc & Barrel bead & 6.89 & 6.88 & 2.31 & Andévalo Oriental \\
\hline DPH-1130 & Puerto Huertos & Muscovite & Spherical bead & 6.99 & 11.01 & 2.76 & Andévalo Oriental \\
\hline DPH-1154 & Puerto Huertos & Muscovite & Barrel bead & 10.00 & 8.31 & 2.79 & Andévalo Oriental \\
\hline DPH-1159 & Puerto Huertos & Muscovite & Biconical bead & 10.11 & 7.44 & 2.26 & Andévalo Oriental \\
\hline DPH-1164 & Puerto Huertos & Muscovite & Barrel bead & 12.91 & 10.42 & 2.51 & Andévalo Oriental \\
\hline DPH-1165 & Puerto Huertos & Muscovite & Barrel bead & 4.46 & 3.69 & 1.14 & Andévalo Oriental \\
\hline DPH-1175 & Puerto Huertos & Muscovite & Barrel bead & 11.4 & 11.02 & 3.66 & Andévalo Oriental \\
\hline DPH-1177 & Puerto Huertos & Chlorite & Little discoidal bead & 1.19 & 4.72 & 2.14 & Andévalo Oriental \\
\hline DPH-1184 & Puerto Huertos & Muscovite & Spherical bead & 11.41 & 11.27 & 3.14 & Andévalo Oriental \\
\hline DPH-1238 & Puerto Huertos & Talc & Cylindrical bead & 13.34 & 11.64 & 5.33 & Cuenca media del río Guadiana \\
\hline 4348 & T1 Perdigões & Muscovite & Big discoidal bead & 2.24 & 5.89 & 1.59 & Cuenca media del río Guadiana \\
\hline 4343 & T1 Perdigões & Variscite & Big discoidal bead & 5.26 & 8.62 & 2.02 & Cuenca media del río Guadiana \\
\hline 7163 & T1 Perdigões & Variscite & Spherical bead & 3.87 & 6.24 & 2.06 & Cuenca media del río Guadiana \\
\hline 7289 & T1 Perdigões & Variscite & Barrel bead & 12.24 & 8.82 & 2.71 & Cuenca media del río Guadiana \\
\hline 7547 & T1 Perdigões & Muscovite & Big discoidal bead & 3.23 & 10.18 & 1.56 & Cuenca media del río Guadiana \\
\hline 7784 & T1 Perdigões & Variscite & Barrel bead & 11.09 & 15.22 & 4.54 & Cuenca media del río Guadiana \\
\hline 7816 & T1 Perdigões & Variscite & Barrel bead & 11.05 & 12.41 & 3.03 & Cuenca media del río Guadiana \\
\hline 7942 & T1 Perdigões & Variscite & Cylindrical bead & 13.85 & 6.69 & 2.73 & Cuenca media del río Guadiana \\
\hline 7944 & T1 Perdigões & Variscite & Spherical bead & 4.71 & 10.03 & 1.94 & Cuenca media del río Guadiana \\
\hline 7906 & T1 Perdigões & Variscite & Spherical bead & 5.12 & 7.76 & 2.66 & Cuenca media del río Guadiana \\
\hline 11821 & T2 Perdigões & Variscite & Spherical bead & 2.16 & 6.59 & 1.34 & Cuenca media del río Guadiana \\
\hline 11822 & T2 Perdigões & Variscite & Spherical bead & 3.99 & 5.94 & 2.18 & Cuenca media del río Guadiana \\
\hline 11823 & T2 Perdigões & Variscite & Barrel bead & 2.92 & 7.56 & 1.25 & Cuenca media del río Guadiana \\
\hline 11825 & T2 Perdigões & Variscite & Barrel bead & 3.64 & 8.09 & 1.73 & Cuenca media del río Guadiana \\
\hline 11827 & T2 Perdigões & Muscovite & Big discoidal bead & 5.20 & 6.27 & 2.14 & Cuenca media del río Guadiana \\
\hline 11835 & T2 Perdigões & Variscite & Spherical bead & 2.49 & 5.84 & 1.69 & Cuenca media del río Guadiana \\
\hline 11824 & T2 Perdigões & Variscite & Spherical bead & 3.58 & 5.24 & 2.18 & Cuenca media del río Guadiana \\
\hline 11826 & T2 Perdigões & Variscite & Spherical bead & 3.59 & 7.83 & 1.54 & Cuenca media del río Guadiana \\
\hline 11838 & T2 Perdigões & Variscite & Spherical bead & 2.48 & 5.41 & 1.02 & Cuenca media del río Guadiana \\
\hline 11839 & T2 Perdigões & Variscite & Barrel bead & 5.02 & 8.15 & 2.44 & Cuenca media del río Guadiana \\
\hline P1 & T3 Pijotilla & Variscite & Barrel bead-pendant & 25.00 & 7.50 & 3.80 & Cuenca media del río Guadiana \\
\hline $\mathrm{P} 2$ & T3 Pijotilla & Variscite & Barrel bead & 15.60 & 10.0 & 5.20 & Cuenca media del río Guadiana \\
\hline$\underline{\mathrm{P} 3}$ & T3 Pijotilla & Muscovite & Big discoidal bead & 3.80 & 2.80 & 2.20 & Cuenca media del río Guadiana \\
\hline
\end{tabular}

XRD, x-ray diffraction. 
earlier model that considers non-hydrogenbonded $\mathrm{PO}_{4}$ and strongly hydrogen-bonded $\mathrm{PO}_{4}$ units together with $\left(\mathrm{Al}(\mathrm{OH})_{2}\right)^{+} \cdot\left(\mathrm{H}_{2} \mathrm{PO}_{4}\right)^{-}$type species. These authors on the basis of the Raman spectra of variscite group minerals demonstrated the presence of multiple anionic species involving phosphate, dihydrogen-phosphate and mono-hydrogenphosphate species. The presence of hydrogenphosphate species in the variscite mineral would result in $\mathrm{P} / \mathrm{Al}$ atomic ratios higher than 1 depending on the exact value and the relative proportions of the different hydrogenphosphate species. Early studies have set up the existence of dihydrogenphosphate species in the genesis of variscite minerals being the hydrogenphosphate solid phase the one precipitated earlier (Hsu, 1982).

In the infrared spectra of geological variscite samples and beads we observe bands at $c a .1100,1150$ and $830 \mathrm{~cm}^{-1}$. These broad bands showing several shoulders are compatible with those described by Frost et al. (2004) in both the symmetric and antisymetric stretching regions of the $\mathrm{PO}_{4}$ units which are claimed by these authors as an indicator of multiple $\mathrm{PO}_{4}$ species.

By obtaining the second derivative of the IR spectra we determine the position of the maxima corresponding to the overlapping vibrational modes, the obtained values are compared with those of the literature (Frost et al., 2004; Tejedor-Tejedor and Anderson, 1990; Farmer, 1977). The vibrational modes ascribed to librational modes of the water molecules present in the variscite structure are observed at frequencies below $900 \mathrm{~cm}^{-1}$ and the modes between 1200 and $900 \mathrm{~cm}^{-1}$ to the stretching frequencies of the $\left[\mathrm{PO}_{4}\right]$ coordination polyhedra. Our IR spectra are consistent with previously reported data and might be ascribed to a mixture of phosphate and hydrogenphosphate species. Therefore, the existence of these hydrogenphosphate species accounts for the $\mathrm{P} / \mathrm{Al}$ ratio reported previously.

These findings suggest the $\mathrm{P} / \mathrm{Al}$ atomic ratio recorded for Pico Centeno massive variscite arose during the genesis of the variscite deposits and resulted from the associated $\mathrm{pH}$ and nature of the host-rocks, modifying the concentrations of $\mathrm{PO}_{4}^{3-}, \mathrm{H}_{2} \mathrm{PO}_{4}^{-}$and $\mathrm{PO}_{4}{ }^{2-}$. Thus, the P/Al atomic ratio should be an indication of provenance as it is established during mineral genesis. This issue has not been addressed in any of the other studied sources where this ratio seems to be $\approx 1$.

The great majority of green beads from Perdigões tholoi 1 and 2 match the ICDD card 25-18 card, as can be seen in Figure 5. There are only 3 beads that do not match variscite pattern and these appear to match muscovite XRD pattern (ICDD 6-263).

La Pijotilla's beads match the variscite XRD pattern in two of the cases and muscovite for the third one. At Andévalo Oriental the use of variscite as raw material for beadwork is completely absent and the preferential mineral of choice is the use of the so-called soapstone (talc, muscovite and chlorite). Of the 25 beads analysed (Table 1), 9 beads were made with talc (ICDD 19-770), 13 with muscovite (Figure 5) and 2 with chlorite (ICDD 1-73-2376).

The compositional data show how it is not possible to discriminate between the three different variscite mines of Pico Centeno, or between the Sierra Concha, El Tejar and Pico Centeno sources according to minor and trace elements. This is contrary to what has been suggested in the literature. In our case study the above-mentioned P/Al atomic ratio allows source provenancing between sources because it is a characteristic of the vein's origins and as such can be used to link the prehistoric mine and the beads and is fully consistent with the beads found at the Middle Guadiana (Figure 6)

As shown in Figure $6 \mathrm{P}$ vs Al plot, the samples from the Pico Centeno mines are clustered together and clearly separated from the other outcrops. They also appear separated from the isolated nodules found distributed around the hill but outside the trenches debris and scars. Samples from Sierra Concha and El Tejar are closer to the mines' cluster but are still separated enough from the core values of the cluster.

\section{Conclusions}

The sampled mineral found in the trench scars, the rough-out nodules, the worked flake scatters and the Middle Guadiana beads are all representative of a hydrogenphosphate species which results in a P/Al ratio much higher than 1. Both the mineral sampled at Pico Centeno and the beads from the Middle Guadiana have similar P/Al atomic ratios, which suggests that the raw material from which they are made comes from Pico Centeno.

The natural variability found in the elemental composition of the trench samples and the overlapping of minor and trace elements values in the mineral does not allow us to discriminate between trenches. It does, however, allow us to differentiate between different outcrops. In this paper we propose that differences in the P/Al atomic ratio might be characteristic of the paragenesis of the mineral, and might constitute a fingerprint of each source.

\section{References}

Cerdán C, Leisner G, Leisner V, 1975. [Los sepulcros megalíticos de Huelva: excava- ciones arqueológicas del Plan Nacional 19461952]. [Book in Spanish]. Comisaria General de Excavaciones Arqueológicas, Madrid.

Farmer VC, 1977. Infrared spectra of minerals. Mineralogical Society of Great Britain \& Ireland, London.

Frost RL, 2004. Raman spectroscopy of phosphates of the variscite mineral group. $\mathrm{J}$ Raman Spectrosc 35:1047-55.

Hsu PH, 1982. Crystallization of variscite at room temperature. Soil Sci 133:305-13.

Hurtado V, 1986. [El Calcolítico en la Cuenca Media del Guadiana y la necrópolis de La Pijotilla]. In: [Actas de la Mesa Rredonda sobre Megalitismo peninsular (Madrid, 1984)]. [Proc. in Spanish]. Madrid.

Hurtado V, 1991. [Informe de las excavaciones de urgencia en "La Pijotilla". Campaña de 1990]. [Article in Spanish]. Extremadura Arqueológica 2:45-67.

Larsen ES, 1942. The mineralogy and paragenesis of the variscite nodules from Near Fairfield, Utah. Am Mineral 27:281-300.

Linares Catela JA, 2006. [Documentación, consolidación y puesta en valor del Conjunto Dolménico de Los Gabrieles (Valverde del Camino, Huelva)]. [Book in Spanish]. Junta de Andalucía, Sevilla, pp 200-14.

Linares Catela JA, 2009. [Análisis arquitectónico y territorial de los conjuntos megalíticos de Los Gabrieles (Valverde del Camino) y El Gallego-Hornueco (BerrocalEl Madroño)]. [Book in Spanish]. Huelva.

Linares Catela JA, García Sanjuán L, 2010. [Contribuciones a la cronología absoluta del megalitismo andaluz. Nuevas fechas radiocarbónicas de sitios megalíticos del Andévalo oriental (Huelva)]. [Article in Spanish]. Revista de prehistoria de Andalucía 1:134-51.

Moro MC, 1992. [Características de las mineralizaciones de variscita asociadas a los materiales silúricos del Sinforme de Terena, Encinasola (Provincia de Huelva). Comparación con las de la provincia de Zamora]. [Article in Spanish]. Boletín de la Sociedad Española de Mineralogía 15:79-89.

Moro MC, 1995. [Las mineralizaciones estratiformes de variscita (Aluminofosfatitas) silúricas de los Sinformes de Alcañices (Zamora) y Terena (Huelva) (España)]. [Article in Spanish]. Boletín Geológico y Minero 106:233-49.

Odriozola CP, 2008. [Datación por técnicas luminiscentes de la tumba 3 y el conjunto campaniforme de La Pijotilla (Badajoz, España)]. In: [VII Congreso Ibérico de Arqueometría]. [Proc. in Spanish]. Instituto de Historia (CSIC), Museo Arqueológico Nacional y SAPaC, Madrid.

Odriozola CP, Linares Catela JA, Hurtado V, 2010. Variscite source and source analysis: 
testing assumptions at Pico Centeno (Encinasola, Spain). J Archaeol Sci 37:3146-57.

Querré G, Herbault F, Calligaro T, 2007. Long distance transport of Neolithic variscite ornaments along the European Atlantic arc demonstrated by PIXE analysis. In: Proceedings of the XI International Conference on PIXE and its analytical applications, Puebla, Mexico, May 25-29

\section{UNAM.}

Querré G, Herbault F, Calligaro T, 2008. Transport of Neolithic variscites demonstrated by PIXE analysis. X-Ray Spectrom 37:116-20.

Tejedor-Tejedor MI, Anderson MA, 1990. Protonation of phosphate on the surface of goethite as studied by CIR-FTIR and electrophoretic mobility. Langmiur 6:602-11.

Valera AC, Lago M, Evangelista Shaw L, 2002.
[Ambientes funerários no complexo arqueológico dos Perdigões: uma análise preliminar do contexto das prácticas funerarias Calcolíticas no Alentejo]. [Book in Spanish]. ERA-Arqueologia.

Weigand PC, Harbottle G, Sayre EV, 1977. Turquoise source and source analysis: Mesoamerica and the Southwestern U.S.A. Academic Press, New York, pp 15-34. 